\title{
Food assistance programs for children afford mixed dietary quality based on $\mathrm{HEI}-2010$
}

\section{Authors: Carmen Byker Shanks \& Teresa Smith}

NOTICE: this is the author's version of a work that was accepted for publication in Nutrition Research. Changes resulting from the publishing process, such as peer review, editing, corrections, structural formatting, and other quality control mechanisms may not be reflected in this document. Changes may have been made to this work since it was submitted for publication. A definitive version was subsequently published in Nutrition Research, [VOL\# 35, ISSUE\# 1, (January 2015)] DOI\# 10.1016/j.nutres.2014.10.009

Byker Shanks, Carmen, and Teresa Smith. "Food Assistance Programs for Children Afford Mixed Dietary Quality Based on HEl-2010." Nutrition Research 35, no. 1 (January 2015): 35-40. doi: 10.1016/j.nutres.2014.10.009 
1 Dietary Quality of Weekend Food Assistance Programs for Children Better than the American

2 Food Supply

3 Carmen Byker, $\mathrm{PhD}^{\mathrm{a}}$ and Teresa Smith, $\mathrm{MS}^{\mathrm{b}, \mathrm{c}}$

$4{ }^{a}$ Montana State University, Department of Health and Human Development, 222 Romney Gym,

5 Bozeman, MT 59717

$6{ }^{\mathrm{b}}$ Gretchen Swanson Center for Nutrition, 8401 West Dodge Road, Suite 100, Omaha, NE 68114, 7 USA

$8{ }^{\mathrm{c}}$ University of Nebraska Medical Center, Department of Health Promotion, Social \& Behavioral

9 Health, UNMC College of Public Health, 984365 Nebraska Medical Center, Omaha, NE 68198-

104365, USA

11 Corresponding Author

12 Carmen Byker, PhD

13 Montana State University

14222 Romney Gym

15 Bozeman, MT 58717

$16 \quad \mathrm{P}(406) 600-7960$

$17 \quad$ F (406) 994-6314 
23 In 2012, 20\% of households with children in the United States (US) identified as food insecure,

24 which compromises their physical, mental, behavioral, and emotional health [1-4]. Further,

25 emerging evidence shows that children from food insecure households are at risk for overweight

26 and obesity, likely persisting into adulthood [2,5-7].

27 Both federal policies (e.g., Healthy, Hunger-Free Kids Act of 2010) and community driven

28 strategies exist to provide supplemental food assistance to food insecure children and their

29 families [8,9]. For instance, the BackPack Program, which is run by Feeding America, works

30 through food banks across the US to serve 230,000 children annually [10]. Communities around

31 the US have implemented models of this program which distribute non-perishable and easy-to-

32 prepare food items to potentially food insecure school students on Fridays in a backpack to help

33 reduce weekend hunger $[11,12]$. The intention of the backpack program model is to supplement

34 the food insecure participant with food items over a weekend, in addition to what the potentially

35 food scarce home is able to provide.

36 While some supplemental food assistance programs have been shown to increase fruit and

37 vegetable purchasing, fruit and vegetable consumption, and juice consumption among low-

38 income women, scant information is available regarding the impacts of backpack programs on

39 dietary behaviors of children [13-15]. A major determinant of healthy food intake among

40 children is the availability and accessibility of these foods within their food environment [16-

41 18]. Assessing the dietary quality of the foods offered as part of supplemental food assistance

42 programs is one way to better understand whether healthy foods are made available and

43 accessible to children. 
44 The Healthy Eating Index-2010 (HEI-2010), which measures compliance with the 2010 Dietary

45 Guidelines for Americans, is a potential tool to assess the diet quality of foods provided in 46 supplemental food assistance programs, such as the BackPack program $[19,20]$. The Healthy

47 Eating Index-2005 (HEI-2005), which preceded HEI-2010, has been utilized to assess the diet 48 quality of foods consumed or offered for individual-level diets, community-, environmental-, and 49 population-level data and other programs and settings [21-23]. For example, the US food supply received a score of 55 out of 100 in an analysis utilizing HEI-2005. Basiotis (2002) proposed that

51 HEI scores $>80$ suggest a "good" diet, HEI scores $<51$ indicate a "poor" diet, and HEI scores in

52 between "need improvement" [24]. The Center for Nutrition Policy and Promotion (CNPP)

53 created HEI-2010 with the ability to assess nutrition intervention programs, food assistance

54 packages, menus, and the US food supply [20].

55 Currently, no peer-reviewed published studies exist that analyze the diet quality of foods offered 56 in the BackPack or similar programs, including utilizing HEI-2010 methodology [19]. The

57 purpose of this study was to utilize HEI-2010 to evaluate the diet quality of foods offered in one 58 state's backpack programs. These results may help to inform strategies for other large-scale,

59 supplemental food assistance programs to improve diet quality among low-income and food 60 insecure children. We hypothesized that resulting HEI-2010 scores would be of average dietary 61 quality in a cross sectional sample of menus from backpack programs.

\section{2. Methods and Materials}

63 This study was conducted utilizing data collected from all existing backpack programs across the 64 state of Montana. The Montana Food Bank Network (MFBN) first initiated the Feeding America 65 BackPack Program model in 2008 [25]. Four other Montana food banks have adopted the same 
model (i.e., Kid Packs, BackPack Program, Backpack for Kids, and Kids Pack Program).

67 Backpacks of food were distributed to 70 schools (reaching a total of 2,889 students) in 2011-

682012 every Thursday or Friday across Montana. The five programs are referred to as Montana

69 backpack programs throughout the remainder of the paper.

70 For the current study, participating Montana backpack programs first provided researchers with

71 at least four weeks of backpack menus from the 2011-2012 academic year. To measure diet

72 quality of foods in the Montana backpack programs, researchers then randomly selected one

73 weekly menu using a cross sectional approach. Weekly menus within the Montana backpack

74 programs were fairly standard, with the same general types and quantities of foods being offered

75 (e.g., Chef Boyardee, beef ravioli in tomato and meat sauce, canned or Chef Boyardee, Spaghetti

76 and Meatballs, canned). Researchers confirmed with each program that the menu provided was

77 representative of food items offered each week. Analysis occurred in 2013. The [blinded]

78 Institutional Review Board declared the study exempt, since no personal and/or identifying

79 information was collected.

\subsection{Measurement}

81 This study utilized the HEI-2010 to measures conformance with the 2010 Dietary Guidelines for

82 Americans $[19,26]$. Methods for the development and validation and researcher use for HEI-

832010 are explained on the United States Department of Agriculture's (USDA) website [27].

84 Analysis using HEI-2010 results in an overall diet quality index, which is made up of 12

85 components for a total of 100 points [26] (Table 1). The sum of the scores for the 12 components

86 is the total HEI-2010 score, which ranges from 0 to 100, with a higher score indicative of a more

87 healthful diet. Of the 12 components, nine assess adequacy of the diet regarding total fruit, whole 
fruit, total vegetables, greens and beans (dark green vegetables and legumes that were not already counted as protein foods), whole grains, dairy, total protein foods, seafood and plant proteins, and fatty acids ((polyunsaturated fatty acids + monounsaturated fatty acids): saturated fatty acids) [26]. The other three components assess foods and nutrients that should be consumed in moderation: refined grains, sodium, and empty calories (i.e., energy from solid fats, alcohol, and added sugars) [26]. With the exception of the fatty acids ratio, HEI-2010 scores use standards that are expressed as either a percent of calories or per 1,000 calories, separating diet quality from quantity $[26,27]$.

\subsection{Statistical Analyses}

A series of steps occurred in order to determine HEI-2010 component and total scores for the Montana backpack programs. First, each menu item with package size was entered into Nutritionist Pro Diet Analysis Module (version 2.5; Axxya Systems, Stafford, TX, USA) and analyzed for nutrient composition (Table 2). Concurrently, the USDA What's In The Foods You Eat online search tool (version 5.0) [28] was utilized to assign the best matched USDA food code to each menu item (Table 2). Next, MyPyramid Equivalents Database for USDA Survey Food Codes, 2003-2004 Version 2 was then used to assign MyPyramid major food groups and subgroups equivalents to each menu item. Finally, HEI-2010 component and total scores were estimated using published SAS code (version 9.2 SAS Institute Inc., Cary, NC) [20]. Following the methodology outlined by Erinosho and colleagues [29], the following analyses were conducted: 1) means and standard deviations ( \pm SD) were calculated to generate both HEI-2010 component scores and 2) total scores across all menus and t-tests were calculated to assess whether mean HEI-2010 component scores and total scores differed significantly $(P<.05)$ from the maximum scores. Montana backpack program scores were compared to HEI-2010 maximum 
111 recommended scores to measure conformance with the 2010 Dietary Guidelines for Americans,

112 an achievable set of recommendations designed to promote health and prevent disease in the US

113 population $[19,26]$.

\section{3. Results}

115 Table 3 describes the HEI-2010 component and total scores for foods and beverages provided to 116 children in the Montana backpack programs. The total HEI-2010 scores ranging from 41.90 to

11775.14 across all five program menus. The mean total HEI-2010 score for the combined Montana 118 backpack program was significantly lower than total HEI-2010 total maximum score of 100 $119($ mean $=58.65 \pm 15.59 ; P=.004)$. Mean scores for total vegetables $($ mean=2.26 $\pm 1.37 ; P=.011)$, 120 greens and beans (mean $=0 \pm 0 ; P<.001$ ), fatty acids (mean=0 $\pm 0 ; P<.001$ ), and sodium

$121($ mean $=3.90 \pm 2.52 ; P=.006)$ were all significantly lower than the maximum values $(5,5,10$, and 12210 , respectively). Remaining component scores were not statistically significantly lower than the 123 respective maximum scores.

124 Contributing to the combined Montana backpack program HEI-2010 score, three program menus $125(60 \%)$ met the requirements for seafood and plant proteins, refined grains, and empty calories. 126 Two of five $(40 \%)$ of the menus achieved the maximum score for total fruit, whole fruit, and 127 whole grains. One of five (20\%) of the menus achieved the maximum score for dairy. None $(0 \%)$ 128 of the menus achieved the maximum score for total vegetables, greens and beans, total protein 129 foods, fatty acids, and sodium.

\section{4. Discussion}

131 Many children in Montana and around the nation participate in backpack programs to 132 supplement their food intake over the weekend [11-12,25]. For many program participants, their 
133 ability to meet nutrition requirements during the weekend depends on the quality of foods

134 provided in weekend backpacks. The research supports the hypothesis that HEI-2010 were of

135 average dietary quality in a cross sectional sample of backpack programs. The food items

136 provided in this nationwide program and similar programs may be contributing to emerging

137 evidence that poverty and food insecurity are not necessarily predictive of nutritional outcomes

138 in children [30,31].

139 The HEI-2010 mean total score of 59 for the Montana backpack programs was slightly better 140 than the American food supply (HEI-2005 score of 55) [22]. However, it was still statistically

141 significantly lower than the maximum score of 100 and fell well below a "good" score of 80

142 [29]. Further, it scored similarly to HEI-2005 score for several groups that have marked

143 overweight, obesity, and nutrition-related chronic diseases [32,33]: American children scored

144 between 54.7 and 59.6 [34]. America adults scored 57.5 [21], and an American supplemental

145 food assistance program scored between 55 and 58 [35]. Scores for each of the five programs in

146 the current ranged from 42 to 75 , demonstrating a wide variation in dietary quality. It would be

147 beneficial to make nutrient-rich foods consistently available and accessible across programs [2,5-

148 7].

149 Prior research has demonstrated a relationship between participation in food assistance programs

150 and other supplemental food programs (e.g. school breakfast) and an increase in food security

151 among children [36,37]. Though information on dietary behavior, especially among children, is

152 limited [36], research shows that increasing promoting access to healthy foods is likely to

153 increase consumption [18]. Specifically in the backpack programs in this current study,

154 increasing the provision of total vegetables, greens and beans, fatty acids while decreasing

155 sodium could enhance the diet quality of Montana backpack programs. Providing dried or 

177 income individuals are likely to have lower quality diets overall [21]. high in nutrients. HEI-2010 does not value fresh over other types of preserved foods in equally to the total HEI-2010 score.

canned vegetables that are appealing to consume such as kale chips or hummus may increase dietary quality in backpack programs. Although the backpack program is limited in providing fresh fruits, vegetables, or other foods consistently due to distribution and storage schedules, programs could focus on providing a variety of non-perishable and easy-to-prepare foods that are calculating diet quality scores. For example, canned carrots or fresh carrots on a menu contribute

While increasing quality may potentially be challenging due to programs conventionally providing shelf-stable or non-perishable and easy-to-prepare food items, information sharing across programs about which food items adhere closely to 2010 Dietary Guidelines could assist in programs adopting healthier practices [19]. For example, several programs scored adequately in food components including seafood and plant proteins, refined grains, and empty calories, total fruit, whole fruit, and whole grains, and dairy. Together, the five programs have the ability to create a backpack program menu that meets the nutrient requirements in several food groups.

Backpack programs and many other food assistance programs aim to provide food that is supplemental to the participant's diet and not the substance of the participant's entire diet. Furthermore, backpack program participants may potentially share food items with other family members or friends, even though that is not the intention of the program [11]. In these scenarios, the entirety of the participant's dietary quality may not be captured through the HEI-2010 analysis presented in this paper. Even so, it is important for backpack programs and other food assistance programs to provide the highest quality nutrients possible as research shows that low- 
178 This study has a few limitations to note. First, the sample of program menus collected from

179 Montana may limit generalizing findings to all supplemental weekend food assistance programs

180 for children in the US. However, all programs were based on the same national model and these

181 findings may be suggestive of a pattern seen across programs in the US. Second, this study

182 assessed foods offered through food assistance packages, which are meant to be supplementary

183 to other foods. Because nutrient values of the food provided in the backpack packages were not

184 provided, the authors estimated these values by determining foods that most closely met the

185 descriptions given from the USDA What's In The Foods You Eat online search tool (version 5.0)

186 [28]. This database is comprehensive and representative of nutrient averages found in the US

187 food supply. The food items served in these programs were single serving items and likely to be

188 consumed over a weekend, but larger or smaller food package sizes may influence the

189 participant's overall dietary quality over varying amounts of times. Lastly, the sample size of

190 backpacks was small. The authors accounted for this limitation by randomizing program menus

191 and checking with programs for representative menus. Despite these limitations, this study adds

192 to the evidence base of information available about the dietary quality of a food assistance

193 package.

194 This is the first peer-reviewed study to evaluate a weekend supplemental food assistance

195 program for children utilizing HEI-2010 or any other dietary quality measurement tool [20].

196 Although the programs examined in this study are designed to be supplemental, small

197 improvements in the menu offerings in Montana backpack programs are warranted in order to

198 promote food security and establish healthy eating patterns, while simultaneously reducing risk

199 for obesity. Studies are needed to assess and compare dietary quality in backpack programs in

200 other states and to test participant's acceptance of food items in the backpack program. In 
201 addition, research should focus on increasing what is known about the larger effects of the 202 backpack program on participants' and families' well-being. Practitioners, researchers, and the 203 food industry should explore, compile, and share what healthy, non-perishable, easy-to-prepare, 204 and affordable foods are both suitable for children and backpack program needs.

205

206 Acknowledgements The authors would like to thank [blinded institution] for funding support for 207 this research. 


\section{References}

[1] Coleman-Jensen A, Nord M, Singh A. Household Food Security in the United States in $2012 ; 2013$.

[2] Kirkpatrick SI, McIntyre L, Potestio ML. Child hunger and long-term adverse consequences for health. Arch Pediatr Adolesc Med 2010;164:754-62.

[3] Melchior M, Caspi A, Howard LM, Ambler AP, Bolton H, Mountain N, et al. Mental health context of food insecurity: a representative cohort of families with young children. Pediatrics 2009;124:e564-e572.

[4] Kleinman RE, Murphy JM, Little M, Pagano M, Wehler CA, Regal K, et al. Hunger in children in the United States: potential behavioral and emotional correlates. Pediatrics 1998;101:e3-e3.

[5] Weinreb L, Wehler C, Perloff J, Scott R, Hosmer D, Sagor L, et al. Hunger: its impact on children's health and mental health. Pediatrics 2002;110:e41.

[6] Alaimo K, Olson CM, Frongillo EA, Briefel RR. Food insufficiency, family income, and health in US preschool and school-aged children. Am J Public Health 2001;91:781-6.

[7] Serdula MK, Ivery D, Coates RJ, Freedman DS, Williamson DF, Byers T. Do obese children become obese adults? A review of the literature. Prev Med 1993;22:167-77.

[8] Food and Nutrition Services, United States Department of Agriculture. Healthy HungerFree Kids Act 2014.

[9] Guo B. Beyond the Public Safety Net: The Role of Nonprofits in Addressing Material Hardship of Low-Income Households. Nonprofit Volunt Sect Q 2010;39:784-801. 
[10] Feeding America. BackPack Program. Available from: http://feedingamerica.org/how-wefight-hunger/programs-and-services/child-hunger/backpack-program.aspx; nd. [Accessed October 9, 2014].

[11] Cotugna N, Forbes S. A BackPack Program provides help for weekend child hunger. J Hunger Amp Environ Nutr 2008;2:39-45.

[12] Rodgers YE, Milewska M. Food assistance through the school system: evaluation of the Food for Kids Backpack program. J Child Poverty 2007:75-95.

[13] Herman DR, Harrison GG, Jenks E. Choices made by low-income women provided with an economic supplement for fresh fruit and vegetable purchase. J Am Diet Assoc 2006;106:740-4.

[14] Herman DR, Harrison GG, Afifi AA, Jenks E. Effect of a targeted subsidy on intake of fruits and vegetables among low-income women in the Special Supplemental Nutrition Program for Women, Infants, and Children. Am J Public Health 2008;98:98-105.

[15] Burr ML, Trembeth J, Jones KB, Geen J, Lynch LA, Roberts ZES. The effects of dietary advice and vouchers on the intake of fruit and fruit juice by pregnant women in a deprived area: a controlled trial. Public Health Nutr 2007;10:559-65.

[16] Patrick H, Nicklas TA. A review of family and social determinants of children's eating patterns and diet quality. J Am Coll Nutr 2005;24:83-92.

[17] Story M, Neumark-Sztainer D, French S. Individual and environmental influences on adolescent eating behaviors. J Am Diet Assoc 2002;102:S40-51.

[18] Baranowski T, Cullen KW, Baranowski J. Psychosocial correlates of dietary intake: advancing dietary intervention. Annu Rev Nutr 1999;19:17-40. 
[19] Dietary Guidelines Advisory Committee. Report of the Dietary Guidelines Advisory Committee on the Dietary Guidelines for Americans, 2010, to the Secretary of Agriculture and the Secretary of Health and Human Services. Agric Res Serv 2010.

[20] US Department of Health \& Human Services, National Institutes of Health, National Cancer Institute. HEI Tools for Researchers. Available from: http://appliedresearch.cancer.gov/hei/tools.html; 2013. [Accessed October 9, 2014].

[21] Guenther PM, Juan W, Lino M, Hiza HA, Fungwe T, Lucas R. Diet quality of low-income and higher income Americans in 2003-04 as measured by the Healthy Eating Index-2005. Nutr Insights 2008.

[22] Reedy J, Krebs-Smith SM, Bosire C. Evaluating the food environment: application of the Healthy Eating Index-2005. Am J Prev Med 2010;38:465-71.

[23] Hiza HAB, Casavale KO, Guenther PM, Davis CA. Diet quality of Americans differs by age, sex, race/ethnicity, income, and education level. J Acad Nutr Diet 2013;113:297-306.

[24] Basiotis PP. The Healthy Eating Index: 1999-2000. Center for Nutrition Policy and Promotion, US Department of Agriculture. http://www.cnpp.usda.gov/sites/default/files/healthy_eating_index/HEI99-00report.pdf; 2002. [Accessed October 9, 2014].

[25] Montana Food Bank Network. BackPack Program. Available from: http://mfbn.org/learn/programs/backpack-program; n.d. [Accessed October 9, 2014].

[26] Guenther PM, Kirkpatrick SI, Reedy J, Krebs-Smith SM, Buckman DW, Dodd KW, et al. The Healthy Eating Index-2010 Is a valid and reliable measure of diet quality according to the 2010 Dietary Guidelines for Americans. J Nutr 2014;144:399-407. 
[27] Department of Health and Human Services, National Institutes of Health, National Cancer Institute. Developing the Healthy Eating Index-2010. Available from:

http://appliedresearch.cancer.gov/hei/developing.html; 2013. [Accessed October 9, 2014].

[28] Ahuja J, Montville J, Omolewa-Tomobi G, Heendeniya K, Martin C, Steinfeldt L, et al. USDA Food and Nutrient Database for Dietary Studies, 5.0. U.S. Department of Agriculture, Agricultural Research Service, Food Surveys Research Group, Beltsville, MD. 2012.

[29] Erinosho TO, Ball SC, Hanson PP, Vaughn AE, Ward DS. Assessing foods offered to children at child-care centers using the Healthy Eating Index-2005. J Acad Nutr Diet 2013;113:1084-9.

[30] Bhattacharya J, Currie J, Haider S. Poverty, food insecurity, and nutritional outcomes in children and adults. J Health Econ 2004;23(4):839-62.

[31] Knol LL, Haughton B, Fitzhugh EC. Food insufficiency is not related to the overall variety of foods consumed by young children in low-income families. J Am Diet Assoc 2004;104(4):640-4.

[32] Flegal KM, Carroll MD, Kit BK, Ogden CL. Prevalence of obesity and trends in the distribution of body mass index among US adults, 1999-2010. JAMA 2012;307:491-7.

[33] Pan L, Sherry B, Njai R, Blanck HM. Food insecurity is associated with obesity among US adults in 12 states. J Acad Nutr Diet 2012;112:1403-9.

[34] Fungwe T, Guenther PM, Juan W, Hiza H, Lino M. Quality of children's diets in 2003-04 as measured by the Healthy Eating Index-2005. Nutr Insights 2009;2009.

[35] Harnack L, Hearst M, Harrison M. Report to Feeding America: evaluation of the nutritional quality of BackPack Program. 
http://fromhungertohealth.files.wordpress.com/2012/05/evaluation-of-the-nutritionalquality-of-backpack-program-menus-final-report.pdf; 2012. [Accessed October 9, 2014].

[36] Black AP, Brimblecombe J, Eyles H, Morris P, Vally H, O'Dea K. Food subsidy programs and the health and nutritional status of disadvantaged families in high income countries: a systematic review. BMC Public Health 2012;12:1099.

[37] Bartfeld JS, Ahn H-M. The School Breakfast Program strengthens household food security among low-income households with elementary school children. J Nutr 2011;141:470-5. 


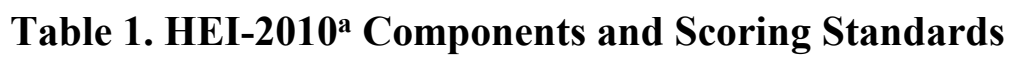

\begin{tabular}{|c|c|c|c|}
\hline Component & $\begin{array}{c}\text { Maxim } \\
\text { um }\end{array}$ & $\begin{array}{c}\text { Standard for Maximum } \\
\text { Score }^{b}\end{array}$ & $\begin{array}{c}\text { Standard for Minimum } \\
\text { Score of Zero }\end{array}$ \\
\hline & Value & & \\
\hline Total Fruit ${ }^{c}$ & 5 & $\begin{array}{c}\geq 0.8 \text { cup equivalent per } \\
1,000 \mathrm{kcal}\end{array}$ & No Fruit \\
\hline Whole Fruit $^{d}$ & 5 & $\begin{array}{c}\geq 0.4 \text { cup equivalent per } \\
1,000 \mathrm{kcal}\end{array}$ & No Whole Fruit \\
\hline Total Vegetables & 5 & $\begin{array}{l}\geq 1.1 \text { cup equivalents per } \\
1,000 \mathrm{kcal}\end{array}$ & No Vegetables \\
\hline Greens and Beans ${ }^{\mathrm{e}}$ & 5 & $\begin{array}{c}\geq 0.2 \text { cup equivalent per } \\
1,000 \mathrm{kcal}\end{array}$ & $\begin{array}{c}\text { No Dark Green Vegetables or } \\
\text { Beans and Peas }\end{array}$ \\
\hline Whole Grains & 10 & $\begin{array}{c}\geq 1.5 \text { oz equivalents per } \\
1,000 \mathrm{kcal}\end{array}$ & No Whole Grains \\
\hline Dairy ${ }^{f}$ & 10 & $\begin{array}{c}\geq 1.3 \text { cup equivalents per } \\
1,000 \mathrm{kcal}\end{array}$ & No Dairy \\
\hline Total Protein Foods ${ }^{g}$ & 5 & $\begin{array}{c}\geq 2.5 \mathrm{oz} \text { equivalents per } \\
1,000 \mathrm{kcal}\end{array}$ & No Protein Foods \\
\hline Seafood and Plant & 5 & $\geq 0.8 \mathrm{oz}$ equivalent per & No Seafood or Plant Proteins \\
\hline Proteins $^{g, h}$ & & $1,000 \mathrm{kcal}$ & \\
\hline Fatty Acids ${ }^{i}$ & 10 & $\begin{array}{c}(\text { PUFAs }+ \text { MUFAs }) / \text { SFAs } \\
>2.5\end{array}$ & $(\mathrm{PUFAs}+\mathrm{MUFAs}) / \mathrm{SFAs} \leq 1.2$ \\
\hline Refined Grains & 10 & $\leq 1.8 \mathrm{oz}$ equivalents per & $\geq 4.3$ oz equivalents per 1,000 \\
\hline
\end{tabular}


$1,000 \mathrm{kcal} \quad \mathrm{kcal}$

Sodium $\quad 10 \leq 1.1 \mathrm{~g}$ per $1,000 \mathrm{kcal} \quad \geq 2.0 \mathrm{~g}$ per $1,000 \mathrm{kcal}$

Empty Calories $^{\mathbf{j}} \quad 20 \quad \leq 19 \%$ of energy $\quad \geq 50 \%$ of energy

Total 100

${ }^{\mathrm{a}} \mathrm{HEI}=$ Healthy Eating Index

${ }^{b}$ Intakes between the minimum and maximum standards are scored proportionately.

${ }^{\mathrm{c} I n c l u d e s ~ f r u i t ~ j u i c e . ~}$

${ }^{\mathrm{d} I n c l u d e s ~ a l l ~ f o r m s ~ e x c e p t ~ j u i c e . ~}$

${ }^{\mathrm{e}}$ Includes any beans and peas not counted as Total Protein Foods

fIncludes all milk products, such as fluid milk, yogurt, and cheese, and fortified soy beverages.

gBeans and peas are included here (and not with vegetables) when the Total Protein Foods standard is otherwise not met.

${ }^{\mathrm{h}}$ Includes seafood, nuts, seeds, soy products (other than beverages) as well as beans and peas counted as Total Protein Foods.

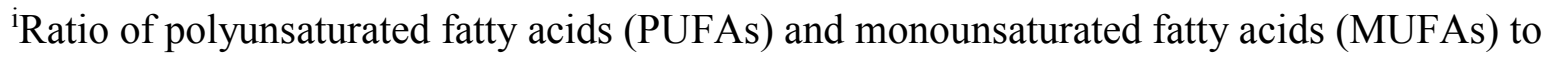
saturated fatty acids (SFAs).

${ }^{\mathrm{j}}$ Calories from solid fats, alcohol, and added sugars; threshold for counting alcohol is $>13$ $\mathrm{g} / 1,000 \mathrm{kcal}$. 
Table 2. Food Codes, Number Of Items, Food Items, and Package Size for Menus in Montana Backpack Food Assistance Programs

\begin{tabular}{|c|c|c|c|}
\hline USDA $^{\text {a }}$ Food Code & $\begin{array}{l}\text { No. o } \\
\text { Item }\end{array}$ & f & $\begin{array}{c}\text { Package Size } \\
\text { (in Grams) }\end{array}$ \\
\hline \multicolumn{4}{|l|}{ Program Menu $1^{b}$} \\
\hline 63103120 & 1 & Applesauce, unsweetened, canned & 113.4 \\
\hline 73102213 & 1 & Carrots, canned & 113.4 \\
\hline 58130013 & 1 & $\begin{array}{l}\text { Chef Boyardee, beef ravioli in tomato and } \\
\text { meat sauce, canned }\end{array}$ & 198.4 \\
\hline 53542200 & 2 & Granola bar, oat, fruit and nut & 34.01 \\
\hline 42202000 & 2 & Jif creamy peanut butter & 31.2 \\
\hline 64100110 & 1 & $\begin{array}{l}\text { Juice, fruit blend, } 100 \% \text { juice, with added } \\
\text { vitamin c }\end{array}$ & 209.6 \\
\hline 58145114 & 1 & Kraft macaroni and cheese, unprepared & 175.0 \\
\hline 11111160 & 2 & Milk, low fat, $1 \%$ & 244.0 \\
\hline 57602100 & 1 & Oats, raw & 30.0 \\
\hline \multicolumn{4}{|l|}{ Program Menu 2} \\
\hline 58130013 & 1 & Lasagna with meat, canned & 212.6 \\
\hline 58160150 & 1 & Red beans and rice & 212.6 \\
\hline 61213220 & 1 & Tangerine juice, canned, unsweetened & 126.8 \\
\hline 92530810 & 1 & Grapefruit juice drink with vitamin $\mathrm{C}$ added & 126.8 \\
\hline 57305210 & 1 & Malt-O-Meal Frosted Flakes & 28.4 \\
\hline 57305500 & 1 & Malt-O-Meal Honey and Nut Toasty O's & 28.4 \\
\hline
\end{tabular}


53540200

53206000

11111160

Program Menu 3

11111160

61210250

63103120

74602100

58407050

57123000

57602100

91708030

Program Menu 4

57123000

42202000

57602100

54202010

58145114

63103120

53542200

64104010

1 Breakfast bar, cereal crust with fruit filling, lowfat 34.0

1 Cookie, chocolate chip

39.1

244.0

244.0

1 Orange juice, with calcium added, canned, bottled 202.5 or in a carton, unsweetened

1 Applesauce, unsweetened, canned

113.4

1 Tomato soup, canned, low sodium, ready-to-serve 205.5

1 Instant soup, noodle with egg, shrimp or chicken $\quad 85.0$

1 Cheerios

17.7

1 Oats, raw

30.0

1 Fruit leather

14.2

1 Cheerios 34.0

$1 \quad$ Jif creamy peanut butter $\quad 31.8$

$1 \quad$ Oats, raw 30.0

3 Crackers, saltine, low sodium $\quad 5.7$

$1 \quad$ Kraft macaroni and cheese, unprepared $\quad 56.7$

$1 \quad$ Applesauce, unsweetened, canned 113.4

1 Granola bar, oats, fruit and nuts, lowfat $\quad 34.0$

1 Apple juice $\quad 180.0$ 


\section{Program Menu 5}

$11111160 \quad 2 \quad$ Milk, low fat, $1 \% \quad 244.0$

$91708100 \quad 1 \quad$ Fruit snack candy, with added vitamin C 28.0

$\begin{array}{lll}54401020 & 1 & \text { Salty snacks, corn or cornmeal base, corn chips, } \quad 60.2\end{array}$ corn-cheese chips

$\begin{array}{llll}57602100 & 1 & \text { Cheerios } & 36.9\end{array}$

$\begin{array}{llll}57349000 & 1 & \text { Frosted Flakes, Kellogg } & 59.5\end{array}$

$\begin{array}{lll}92510610 & 2 & \text { Fruit drink }\end{array}$

$58132313 \quad 1 \quad$ Pasta with tomato sauce and meat or meatballs, $\quad 240.0$ canned

$58130013 \quad 1 \quad$ Chef Boyardee, beef ravioli in tomato and meat $\quad 198.4$ sauce, canned

$53544200 \quad 1 \quad$ Granola bar, chocolate-coated $\quad 24.0$

$53542200 \quad 1 \quad$ Granola bar, oats, fruit and nuts, lowfat $\quad 35.0$

${ }^{a} U S D A=$ United States Department of Agriculture

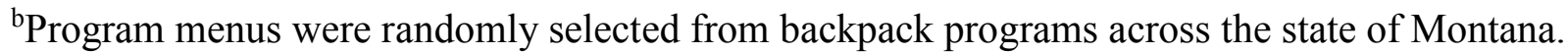
Menus are representative of weekly food item offerings. 
Table 3. HEI-2010 ${ }^{\text {a }}$ Component and Total Scores for Foods and Beverages Provided to Children in Five Montana Backpack Food Assistance Programs

\begin{tabular}{|c|c|c|c|}
\hline Component & Means ( \pm SD) & Range & $\begin{array}{c}\text { \% Meeting } \\
\text { Recommendation (n) }\end{array}$ \\
\hline Total Fruit $^{\mathrm{b}}$ & $4.11( \pm 1.36)$ & $1.74-5.00$ & $0.40(2)$ \\
\hline Whole Fruit $^{b}$ & $2.96( \pm 2.26)$ & $0.42-5.00$ & $0.40(2)$ \\
\hline Total Vegetables $^{b}$ & $2.26( \pm 1.37)^{*}$ & $0-3.72$ & $0.00(0)$ \\
\hline Greens and Beans ${ }^{b}$ & $0.00( \pm 0.00)^{* * *}$ & 0.00 & $0.00(0)$ \\
\hline Whole Grains $^{\text {b }}$ & $7.57( \pm 2.40)$ & $4.53-10$ & $0.40(2)$ \\
\hline Dairy $^{b}$ & $9.10( \pm 0.89)$ & $\begin{array}{l}7.79- \\
10.00\end{array}$ & $0.20(1)$ \\
\hline Total Protein Foods ${ }^{b}$ & $2.93( \pm 1.89)$ & $0.45-4.82$ & $0.00(0)$ \\
\hline Seafood and Plant Proteins ${ }^{b}$ & $3.13( \pm 2.56)$ & $0.22-5.00$ & $0.60(3)$ \\
\hline Fatty Acids $^{\text {b }}$ & $0.00( \pm 0.00)^{* * *}$ & 0.00 & $0.00(0)$ \\
\hline Refined Grains ${ }^{c}$ & $6.92( \pm 4.27)$ & $\begin{array}{l}1.35- \\
10.00\end{array}$ & $0.60(3)$ \\
\hline Sodium $^{c}$ & $3.90( \pm 2.52)^{* *}$ & $0-6.64$ & $0.00(0)$ \\
\hline Empty Calories ${ }^{c}$ & $15.76( \pm 6.17)$ & $\begin{array}{l}6.45- \\
20.00\end{array}$ & $0.60(3)$ \\
\hline Total & $58.65( \pm 15.59)^{* *}$ & $\begin{array}{l}41.90- \\
75.14\end{array}$ & -- \\
\hline \multicolumn{4}{|c|}{ *Mean scores were significantly different from the maximum recommended scores at the $P<.05$} \\
\hline
\end{tabular}


**Mean scores were significantly different from the maximum recommended scores at the $P<$

.01 level.

***Mean scores were significantly different from the maximum recommended scores at the $P<$

.001 level.

${ }^{\mathrm{a}} \mathrm{HEI}=$ Healthy Eating Index

${ }^{\mathrm{b}}$ Higher score signifies higher consumption as adequate consumption of these foods is encouraged by the 2010 Dietary Guidelines.

${ }^{c}$ Higher score signifies lower consumption as moderate consumption of these foods is encouraged by the 2010 Dietary Guidelines. 